\title{
BEIJA-FLOR DE NILÓPOLIS E NILÓPOLIS DA BEIJA-FLOR: MECANISMOS DE UMA CONSTRUÇÃO IDENTITÁRIA E DE PODER NA BAIXADA FLUMINENSE
}

\section{Beija-Flor de Nilópolis and Nilópolis da Beija-Flor: mechanisms of a construction of identity and power in the Baixada Fluminense}

Enderson Alceu Alves Albuquerque Doutorando em Geografia pelo PPGEO-UERJ endersonalbuquerque@yahoo.com.br

Artigo enviado para publicação em 16/07/2018 e aceito em 10/09/2018

DOI: $10.12957 /$ tamoios.2018.36051

\section{RESUMO}

De pouca expressão no contexto econômico da Região Metropolitana do Rio de Janeiro (RMRJ), a Escola de Samba Beija-Flor de Nilópolis empresta ao município que a sedia um lugar de destaque no aspecto cultural em escala nacional. Devido a essa característica e a sua importância enquanto formadora de identidade, a Agremiação foi apropriada por um grupo familiar que passou a utilizá-la como ferramenta política. Com efeito, o trabalho em questão pretende analisar as articulações e o modus operandi que possibilitaram a esse clã manter o controle político da cidade, tendo como pano de fundo o uso da referida instituição carnavalesca. A investigação apontou que esse domínio se estabeleceu de forma mais assertiva a partir da segunda metade da década de 1970, quando a Escola de Samba passou a ter maior notoriedade nas disputas carnavalescas e foi posteriormente ampliado através da associação estabelecida entre esses membros políticos e as ações sociais promovidas pela Beija-Flor no município.

Palavras-chave: Identidade; Beija-Flor; Nilópolis.

\begin{abstract}
Of little expression in the economic context of the Metropolitan Region of Rio de Janeiro (RMRJ), the School of Samba Beija-Flor of Nilópolis lends to the municipality that places it a prominent place in the cultural aspect in national scale. Due to this characteristic and its importance as an identity trainer, the group was appropriated by a family group that began to use it as a political tool. In effect, the work in question intends to analyze the political practice, the articulations and the modus operandi that enabled this clan to maintain the political control of the city, against the background of the use of the mentioned carnival association. The investigation pointed out that this domain was established more assertively from the second half of the decade of 1970 when the School of Samba began to have greater notoriety in the carnival disputes and was later extended through the association between the political members and the social actions of the Beija-Flor promoted in the municipality.
\end{abstract}

Keywords: Identity; Beija-Flor; Nilópolis. 


\section{INTRODUÇÃO}

Algumas cidades são conhecidas através de atributos externamente relacionadas a elas como uma atividade econômica, uma festa cultural ou o fato de ser cidade natal de alguma celebridade. No caso específico de Nilópolis, sua difusão está associada ao fato de ser sede da Agremiação carnavalesca Beija-Flor. Do mesmo modo que uma empresa, dependendo da dimensão de suas atividades e importância para a composição do PIB municipal apresenta considerável peso decisório sobre as políticas públicas estabelecidas em âmbito municipal, instituições culturais podem igualmente exercer essa influência. Nesta perspectiva se desenvolve o presente artigo.

Bonnemaison (2002, p.101-102) por sua vez, assevera que "é pela existência de uma cultura que se cria um território e é por ele que se exprime a relação simbólica existente entre a cultura e o espaço". Assim, o caso da Escola de Samba Beija-Flor é emblemático por mostrar com uma instituição plasmou uma identidade em um espaço, nesse caso o nilopolitano.

A metodologia empregada consistiu na revisão de literatura sobre os conceitos envolvidos na pesquisa e em levantamentos de dados junto a instituições como o IBGE e o TCE, além de sites e revistas especializadas em carnaval. O caminho de investigação escolhido para o trabalho foi o da lógica da descoberta orientada pela questão central a qual a seguinte discussão: Qual o papel desempenhado pela Escola de Samba Beija-Flor para o exercício e a expansão de poder da referida família no contexto de Nilópolis? Tal questionamento se coloca como condição inicial para entender as especificidades do território nilopolitano no atual contexto. Na tentativa de responder a questão central, subquestões se impõem tal como: De que maneira a identidade nilopolitana foi construída em torno da Agremiação carnavalesca? Até que ponto a realidade socioeconômica do município explica o protagonismo dessa instituição cultural como formadora exclusiva da identidade municipal?

Para responder a tais questões, este artigo se divide em três partes. Na primeira apresentaremos uma análise sobre a realidade socioeconômica do município no qual a Agremiação em tela está sediada e estabeleceremos a evolução institucional da Escola de Samba nilopolitana, desde bloco carnavalesco até a primeira metade da década de 1970. A partir de 1976, o destaque alcançado por essa Agremiação nas disputas carnavalescas foi capaz de originar um orgulho de ser nilopolitano, de ser morador "da cidade da Beija-Flor". Nesse período, a Agremiação passou a produzir uma identidade incontestável em Nilópolis, convertendo-a, posteriormente, em uso político. Por essa razão, a segunda parte deste artigo, sob o título de "A Agremiação acima do município: a mecânica da produção identitária em Nilópolis através da Beija-Flor”, se dedica a analisar a gênese da construção dessa identidade até o momento em que ela se consolida como a mais forte entre os munícipes. Por sua vez, o poder identitário ancorado nesta instituição permitiu a seus gestores extrair benefícios políticos e, por esse motivo, a terceira parte investiga tal processo com o título "Identidade construída, uso político determinado: carnaval e política no contexto nilopolitano". Nesta parte consideraremos a natureza dessa conversão bem como suas implicações políticas para o referido município.

\section{DE BLOCO CARNAVALESCO A ESCOLA DE SAMBA: "OLHA A BEIJA- FLOR AÍ, GENTE!"}

Nilópolis localiza-se na Região Metropolitana do Rio de Janeiro (RMRJ) e, embora oficialmente ocupe uma área de $19,157 \mathrm{~km}^{2}$, segundo o Instituto Brasileiro de 
Geografia e Estatísticas (IBGE), apenas $9 \mathrm{~km}^{2}$ são ocupados por sua população de 157.425 residentes de acordo com o último Censo Demográfico. Esses números conferem ao município uma densidade demográfica de cerca de $8.117,62 \mathrm{hab} . / \mathrm{km}^{2}$. A instalação desse município, desmembrado de Nova Iguaçu, ocorreu em 1947. Contudo, os termos nos quais se efetivou essa emancipação responde por sua pequena extensão territorial, exatamente no período em que o processo de industrialização era o principal motor de desenvolvimento econômico no país. Nessa conjuntura, Nilópolis já nasceu excluída das possibilidades industriais e, com o passar do tempo, suas discrepâncias econômicas aumentaram em relação a algumas cidades da Baixada Fluminense, tornando-a pouco participativa na composição do PIB total da Região Metropolitana do Rio de Janeiro (RMRJ).

$\mathrm{Na}$ esfera econômica Nilópolis apresenta índices econômicos pífios quando comparado a alguns municípios da Baixada Fluminense e da RMRJ. Para o ano de 2012 o PIB total da Região Metropolitana na qual o município está inserido foi de R\$ 261. 090. 608 (em mil reais). Nilópolis contribui com apenas 0,74\% desse valor, com um PIB de R\$ 1. 935.707 (MARAFON et. al., 2011). Com efeito, entre os 19 municípios integrantes da RMRJ naquele período, Nilópolis possui o $11^{\circ}$ PIB da região. Considerando os 13 municípios da Baixada Fluminense, nosso recorte espacial detém o $7^{\circ}$ produto interno bruto (TCE, 2014).

Internamente, a participação dos setores econômicos indica o destaque das atividades de serviços na composição econômica de Nilópolis, correspondendo a cerca de $90 \%$ do PIB do município (TCE, 2014). Uma explicação para essa concentração pode ser formulada a partir de sua área urbana, a qual inviabiliza a existência das atividades primárias e compromete o rendimento do setor secundário.

Em face desse quadro econômico, o destaque da cidade no cenário estadual e nacional é protagonizado pela Escola de Samba Beija-Flor de Nilópolis, sediada no município. O fato de essa Agremiação carnavalesca ser a principal referência externa do município concede a ela relevante notoriedade na formação identitária entre os moradores, ao mesmo tempo em que favorece o ganho político de seus dirigentes. Nesse caso específico, em consonância com, a produção coletiva de identidade está a serviço de um poder. Desse modo, o território cultural, que precede aos demais, reforça a construção dos territórios "político-econômicos", para o exemplo nilopolitano.

Outros municípios da Baixada Fluminense, como Duque de Caxias, sedia uma Escola de Samba de expressão no carnaval fluminense, a Grande Rio. Entretanto, a referência desse município não se remete unicamente a essa Agremiação carnavalesca em razão de seu considerável desenvolvimento econômico, alicerçado, principalmente, em seu pólo petroquímico. Em menor expressão nesse contexto, há ainda as Escolas de Samba Leão de Iguaçu, em Nova Iguaçu e Inocentes de Belford Roxo. Como a importância dessas agremiações se dilui simbolicamente entre os moradores com outras referências, sobretudo as econômicas, essas instituições não sobressaem no contexto local. Devido a essa concorrência, os membros dirigentes dessas Escolas de Samba não se tornaram figuras políticas de grande peso em seus municípios.

As Escolas de Samba, por sua vez, foram fundadas, mormente, pelos mesmos organizadores dos blocos de rua e utilizando as concepções artísticas das Sociedades Carnavalescas, como os carros alegóricos a partir de 1926. Considerada a primeira Escola de Samba, “A Deixa Falar”, posteriormente rebatizada para Estácio de Sá, surgiu no morro do Estácio. Mangueira, em 1928 e Unidos da Tijuca em 1931, formam a tríade das agremiaçõos mais antigas ${ }^{1}$.

Com o apoio do jornal "Mundo Sportivo", em 1932 aconteceu o primeiro desfile das Escolas de Samba do Rio de Janeiro na Praça Onze. Devido ao êxito do evento, em 
1935 o prefeito da cidade do Rio de Janeiro, Pedro Ernesto, oficializou as Escolas de Samba. Essa oficialização obrigava as Escolas a possuir estatutos sociais e alvará. Cumpridas essas exigências, a instituição passava a utilizar a sigla GR (Grêmio Recreativo), permitindo-lhes vida jurídica legal e uma verba pública para fomentar seu carnaval.

O primeiro registro de evento carnavalesco em Nilópolis ocorreu no período em que a localidade ainda era $7^{\circ}$ Distrito de Nova Iguaçu. De acordo com Cardoso (1938, p. 45), "um grupo de pessoas de destaque social [...], levou a effeito, no dia 10 de janeiro de 1921, a primeira batalha de "confetti' em Nilópolis". Segundo o autor, as primeiras associações carnavalescas no município foram os Borboletas Vaidosas (1914), Flores de Nilópolis (1918), Teimosos de Nilópolis (1924), Bloco Trovadores de Nilópolis (1924), Caprichosos de Nilópolis (1924) e Paladnios de Nilópolis (1927). Entretanto, o principal bloco carnavalesco, responsável em grande medida pela existência midiática do município, surgiu apenas em 1948, a Associação Carnavalesca Beija-Flor, no dia em 25 de dezembro daquele ano.

De forma semelhante às Agremiações do Rio de Janeiro, em Nilópolis a BeijaFlor surgiu do desmonte dos blocos Irineu Perna-de-Pau e dos Texeiras. O primeiro bloco, por sua vez, era composto por integrantes do Clube Santa Rita (REVISTA DA BEIJA-FLOR, 2002). Além de parte dos integrantes fundadores, a Agremiação carnavalesca recebeu as cores do Clube Santaritense.

Existem quatro versões para a escolha do nome do pássaro para a Associação Carnavalesca. A primeira defende que a mãe de um dos fundadores, Dona Eulália, sugeriu Beija-Flor por simplesmente gostar do pássaro. A segunda versão sustenta que a escolha foi influenciada por uma fazenda mineira de mesmo nome. Outras fontes dizem que o nome faz referência a um rancho carnavalesco já existente, o qual desfilava pelas ruas do município de Mesquita e a última versão, a qual flerta com a mística e por razão tornou-se a mais difundida, afirma que um Beija-Flor apareceu no exato momento em que se discutia o nome do bloco. O carnaval de 1949 foi o primeiro em que a Associação Carnavalesca desfilou em Nilópolis, "quando cerca de 40 foliões botaram o bloco na rua com instrumentos herdados das agremiações anteriores, sem fantasias, mas com muita animação. No ano seguinte, já vestidos de azul e branco, conquistaram o público", conforme registrou a Revista Beija-Flor (2002, p. 11). A mesma publicação traz uma foto do ano seguinte (Figura 1), no qual a Associação desfilou na Avenida Mirandela, principal via local do município de Nilópolis.

Figura 1- Registro fotográfico do Bloco Beija-Flor em 1950. Fonte: Revista Beija-Flor (2002, p. 11).

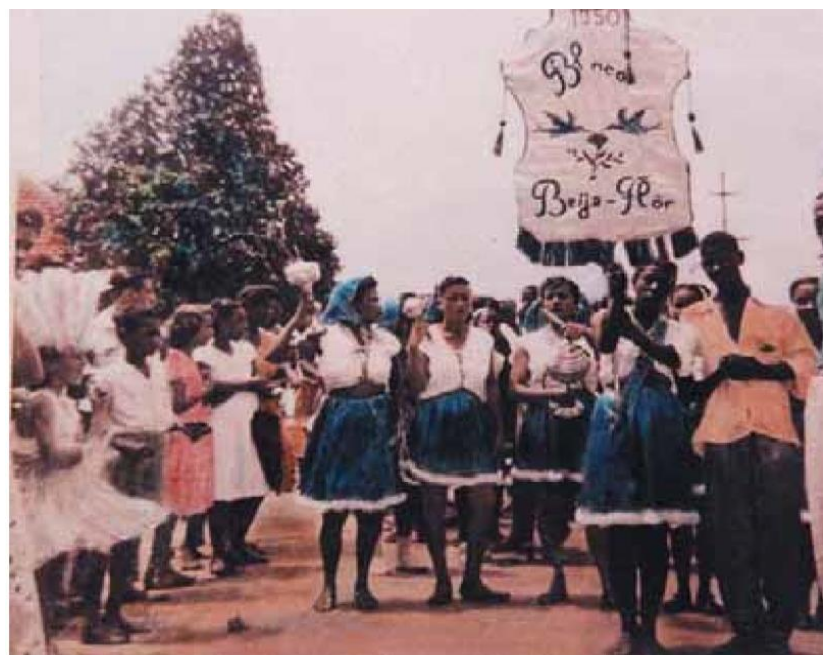


Somente em 1953 a Associação virou Grêmio Recreativo quando se inscreveu na Confederação das Escolas de Samba. No ano seguinte a escola da Baixada Fluminense apresentou o enredo "O caçador de Esmeraldas", tratando dos Bandeirantes e suas contribuições para o desbravamento territorial do Brasil. No ano de sua estréia nas disputas carnavalesca, a Beija-Flor foi campeã do então grupo 2. No ano seguinte, 1955, a escola fez sua primeira apresentação no grupo principal do carnaval ficando na $6^{\mathrm{a}}$ posição.

Entre os anos de 1955 e 1963 a azul e branco nilopolitana permaneceu na elite do carnaval. Todavia, com exceção de 1962, ano no qual ficou em segundo lugar com o enredo "Dia do Fico" narrando fatos referentes ao evento histórico nacional, a BeijaFlor havia conquistado colocações modestas. Nesse período a Agremiação obteve, além das posições mencionadas, por uma vez a $7^{\circ}$, a $8^{\circ}$ e a $9^{\circ}$ colocação na disputa, e em três anos $(1956,1958$ e 1963$)$ a $10^{\circ}$ posição. No último ano em que ficou na $10^{\circ}$ posição, a Escola foi rebaixada para o grupo 2. "Somente a força popular não foi suficiente para manter a escola na elite, naquela época os recursos eram escassos, a subvenção pública era pequena e o município, recém emancipado, não possuía grandes quantias a investir" (SANT'ANNA JUNIOR, 2010, p. 38).

No ano em que regressou para grupo 2, A Beija-Flor apresentou o enredo "Café, riqueza do Brasil", ficando com a $12^{\circ}$ posição. Devido ao resultado, a Agremiação foi novamente rebaixada, dessa vez para o grupo 3. A Escola de Nilópolis permaneceu nesse grupo por três carnavais até 1967, quando conquistou o vice-campeonato com enredo sobre a queda da monarquia.

De volta ao grupo 2 em 1968, a família Abraão David iniciou sua aproximação oficial com a Agremiação dando início a uma relação existente até o período atual: o binômio carnaval e poder no contexto nilopolitano. Nesse ano, Anísio Abraão assumiu de forma interina a presidência da Escola. No ano seguinte o cargo foi assumido por Heitor Silva, o qual permaneceu até 1972. Apesar da aproximação e do auxílio financeiro da família Abraão, a Beija-Flor continuou no grupo de acesso até 1973, quando apresentou o enredo "Educação para o desenvolvimento" obtendo a $2^{\circ}$ posição e, consequentemente, o regresso para a elite do carnaval.

A característica culturalista das temáticas beijaflorianas permaneceu após o ano de 1972, contudo, passou a competir com enredos de conteúdo mais político. Essa alteração teve início no ano seguinte quando a Agremiação retornou ao principal grupo do carnaval sob a presidência de Nelson Abraão David. Desde essa volta, a Agremiação não tornou a ser rebaixada. Em 2018, a Beija-Flor completou 44 anos seguidos na elite do carnaval do Rio de Janeiro. Nessas mais de quatro décadas, a Agremiação conquistou 13 títulos e em apenas em quatro disputas (1974, 1975, 1992 e 2014), nas quais amargou a $7^{\circ}$ posição, não ficou entre as seis melhores colocadas, conforme aponta o quadro 2. Se em 1973 Nelson era o Abraão responsável pela gestão da instituição, em 2018, após 45 anos, o Abraão que a comanda é seu sobrinho, Ricardo.

Da mesma forma que a contagem do tempo no Ocidente, compreender a história da Beija-Flor exige considerar um "antes" e um "depois". Descontadas às devidas proporções, enquanto o nascimento de Cristo tornou-se o divisor histórico para o Ocidente, as gestões dos Abraão tornaram-se os divisores de água para contar a história da Beija-Flor. Até 1976, ano em que conquistou o primeiro campeonato na elite do samba, a azul e branco de Nilópolis era apenas uma escola pequena no mundo do samba que transitava entre o primeiro e o segundo grupo do carnaval. A partir da segunda metade da década de 1970 a Beija-Flor passou a ocupar papel de destaque entre as grandes Agremiações do carnaval carioca. 
Essa ascensão só foi possível em razão do aporte financeiro de um mecenas da contravenção nascido e sediado em Nilópolis: Aniz Abraão David. Sob o domínio da família Abraão, a família Beija-Flor se fortaleceu e consolidou-se entre as maiores potencias do carnaval do Rio de Janeiro. Enquanto esta primeira parte analisou a BeijaFlor no período A/A- antes dos Abraão, a segunda e a terceira partes deste artigo objetivam analisar o momento D/A, no qual a Escola de Samba passou a ser a principal instituição para produzir identidade positiva na Baixada Fluminense e como esse processo identitário está no cerne da construção de um território sólido em Nilópolis.

\section{A AGREMIAÇÃo ACIMA do MUNICÍPIO: A MECÂNICA DA PRODUÇÃo IDENTITÁRIẢ EM NILÓPOLIS ATRAVÉS DA BEIJA-FLOR}

A RMRJ é marcada por seu caráter altamente concentrador. Nesse sentido, a cidade do Rio de Janeiro, por ter sido, também, capital do país entre 1763 e 1960, agregou historicamente serviços de diferentes naturezas. A pujança política e econômica da cidade foi responsável em atrair população de outras regiões do Brasil e de extratos sociais distintos. Essa dimensão concentradora do Rio de Janeiro no aspecto cultural atinge também a geografia das Escolas de Samba do carnaval fluminense. Considerando todas as Escolas de Samba do estado do Rio de Janeiro que concorrem nos grupos, Especial, A, B, C, D, e E, atualmente existem 86 Agremiações. Desse total, apenas 19 instituições carnavalescas não são sediadas na cidade do Rio de Janeiro. A distribuição espacial das escolas de samba aparece expressa na figura 2. A análise do mapa da RMRJ aponta para a predominância de Agremiações carnavalescas na Zona Norte do Rio de Janeiro. Nessa porção carioca foram fundadas as Escolas mais antigas do carnaval como a Mangueira e a Unidos da Tijuca. Atualmente pouco mais de $20 \%$ das Escolas de Samba dos seis grupos do carnaval estão na periferia metropolitanaapenas uma Agremiação se encontra fora dos limites metropolitano, a Império de Petrópolis.

Figura 2- Distribuição geográfica das Escolas de Samba da RMRJ

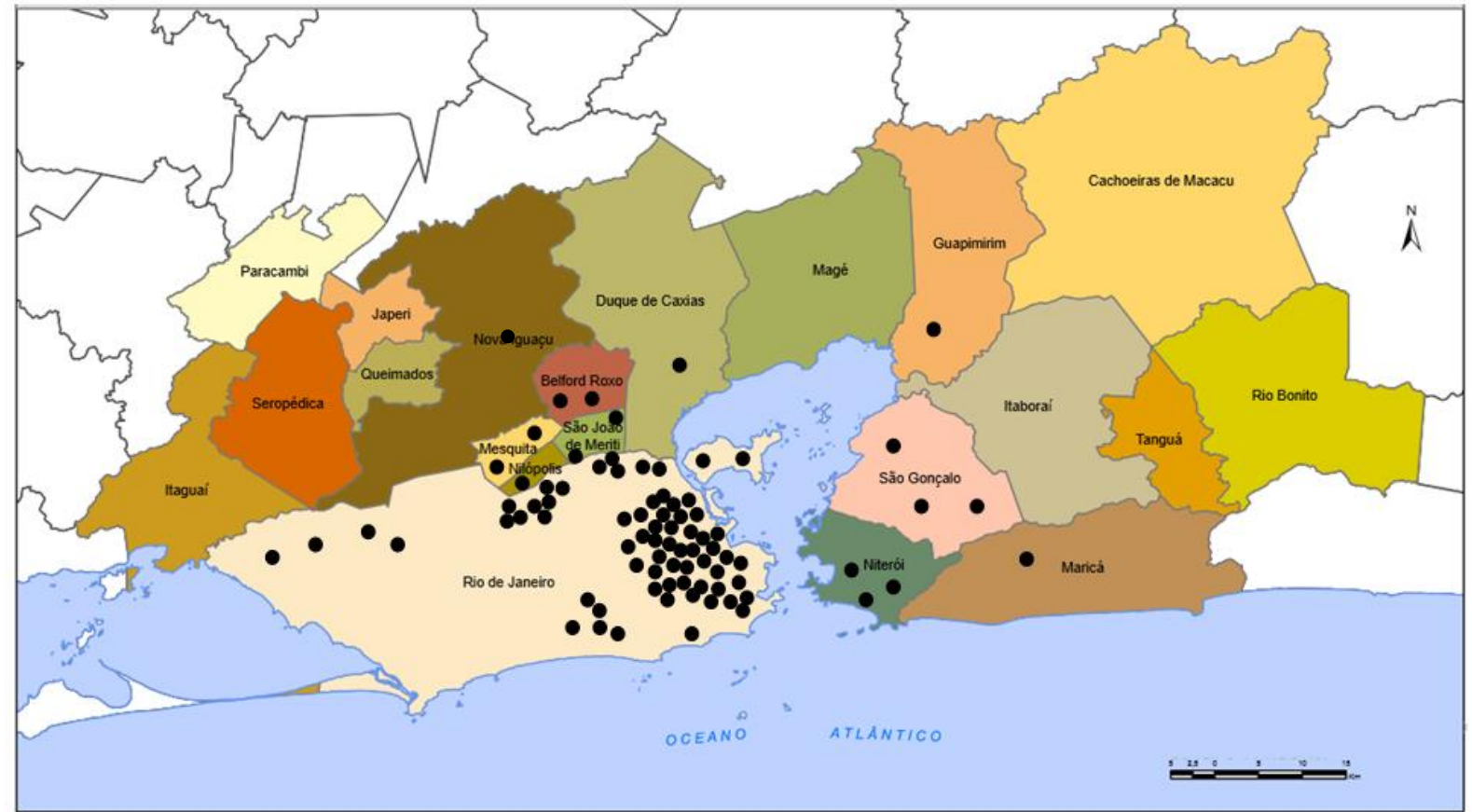

Fonte: Organizado pelo autor a partir de mapa da CEPERJ. 
Entre as 13 Escolas de Samba que já venceram na elite do carnaval fluminense, apenas duas não são da cidade do Rio de Janeiro. A Unidos do Viradouro, campeã apenas em 1997 e a Beija-Flor de Nilópolis, detentora de 13 títulos no grupo principal. Assim, dos 74 carnavais já disputados, o troféu atravessou a ponte Rio - Niterói uma vez, em outras 13 oportunidades rumou para a Baixada Fluminense, porém, em 60 disputas permaneceu no Rio de Janeiro. Mesmo após a emergência de Escolas de Samba fora do núcleo da metrópole, as Agremiações cariocas ainda concentram os títulos. Se hodiernamente vencer as Escolas de Samba da capital é tarefa árdua, em 1976 o desafio era maior. De acordo com matéria publicada na Revista Beija-Flor (2013, p. 23), referindo-se ao carnaval de 1976, "o presidente do Conselho Consultivo, Ary Rodrigues lembra que em todo período que antecedeu o desfile, os colegas e amigos das quatro principais escolas de samba da época brincavam e debochavam da Beija-Flor, chamando-a de "escola da roça"".

Naquele ano, a Agremiação "roceira" impediu o tricampeonato do Salgueiro com a vitória do enredo "Sonhar com Rei dá Leão". Mais que um título carnavalesco, a consagração daquele ano se revestiu de uma redenção sociopolítica maior, pois, de certa forma, a periferia venceu a metrópole e Nilópolis rompeu a hegemonia de Madureira e dos morros do Borel e da Mangueira no reinado do carnaval. Motta (2012, p. 31) revela parte desse sentimento a partir do depoimento de uma integrante da Beija-Flor a qual afirma: "A gente desce com toda a empolgação para ganhar das escolas do Rio".

A vitória da azul e branco de Nilópolis na elite alterou, de fato, a correlação de forças na estrutura carnavalesca do Rio de Janeiro e conduziu a mudança geográfica na premissa do samba. Em matéria publicada no jornal O Globo de 6 de fevereiro de 1976 e reproduzida parcialmente pela Revista Beija-Flor (2016, p. 69), o depoimento de dois entrevistados revela essa alteração:
"é a Beija-Flor e está decidido. Vocês agora, quando quiserem ouvir um samba, vão ter é que tomar um trem até Nilópolis. É isso aí. Acabou o tabu, o tabu mixou." (Nelson Barros, morador de Nilópolis e "fanático" pela Beija- Flor de Nilópolis). "Minha grande alegria com esse resultado é que, a partir de agora, samba não é mais privilégio da Vila, nem de Madureira. O samba é de todo o estado do Rio, principalmente da baixada fluminense" (Roberto Silva, Portelense e morador de Madureira).

A Baixada Fluminense, que até então era identificada amplamente por meio de suas deficiências estruturais e da violência, passava a apresentar outro elemento para servir de associação para os agentes externos com a vitória da Beija-Flor. A identidade das pessoas de um determinado lugar está em larga medida ancorada na concepção desse espaço para os agentes externos a ele. Por essa perspectiva, a ascensão da azul e branco de Nilópolis fornecia um elemento identitário positivo para os moradores da Baixada Fluminense. Foi nesse contexto que a Beija-Flor, sobretudo a partir de 1976 e sedimentado com os posteriores campeonatos de 77 e 78, passou a ser a instituição mais exitosa em produzir, naquele cenário, a identidade entre os moradores não apenas de Nilópolis, mas também entre os moradores dos demais municípios baixadianos.

Com efeito, mais que simplesmente expor a grandiosidade do êxito da Agremiação em tela, pretendemos enfatizar a importância do evento 76, 77, 78 para a consolidação de uma identidade no município. A construção da identidade, por sua vez, "está visceralmente vinculada às relações de poder e a disputa por este poder. Assim, afirmar identidades e definir quem são os diferentes é definir quem vai ter acesso aos bens materiais e simbólicos disponíveis naquele território" (SIMÕES, 2008, p. 38). Norteado por essa premissa, almejamos entender a conotação política da identidade para o contexto nilopolitano a partir da Escola de Samba local. Antes, porém, iniciaremos 
uma discussão conceitual a respeito da identidade para depois delimitarmos a qual tipo de identidade a Agremiação em questão suscita no município considerado.

Defendemos a tese segundo a qual a Agremiação supracitada emana um sentimento identitário consolidado. Tal pressuposto, por sua vez, não assevera que ser nilopolitano esteja diretamente condicionado ao fato de ser torcedor da Beija-Flor. Assim, as duas dimensões relativas a identidade, a individual e a coletiva, apresenta pesos distintos a partir da premissa social pela qual este artigo se encaminha. Isso porque a primeira dimensão de identidade diz respeito a como você se identifica, ou a chamada identidade subjetiva do sujeito (GRACHER, 2016). Esse viés contempla a dimensão mais antropológica, mais individualizada, contudo, implicações daquilo que você é, trazem consequências apenas ao circuito imediato das suas relações sociais.

Em contrapartida, a maneira pela qual as pessoas te identificam conduz a repercussões em escalas maiores. Nesse sentido, a identidade gerada pelos agentes externos tem compromisso somente com os significados, os quais são apenas representações descomprometidas com a realidade em si. Essa identificação elaborada pelos agentes endógenos constitui a chamada identidade coletiva. Por esse processo a identidade municipal de Nilópolis é alicerçada em grande medida sob a Beija-Flor para os agentes externos.

Medeiro (2002, p. 85) considera que essa identidade, de elevado teor simbólico, expõe uma natureza

coercitiva, pois está no desejo do outro em classificar, rotular, normatizar, definir e atribuir ao indivíduo um lugar dentro do social [...]. É o momento que o indivíduo toma conhecimento de como ele é percebido pelo outro. É o início da construção de sua imagem social, pela qual o indivíduo toma conhecimento de sua imagem elaborada pelo grupo, exterior à sua consciência. É o início da construção de sua imagem social, pela qual o indivíduo toma conhecimento de sua imagem elaborada pelo grupo, exterior à sua consciência.

Ainda segundo Medeiro (20002, p.85), para que essa identidade coletiva alcance seu objetivo, é preciso um "processo de interiorização da classificação simbólica que veio de fora. Portanto, é necessário que haja identificação do sujeito com os valores com os quais se vai identificar". Contudo, nem sempre esses valores simbólicos associados a ele encontram respaldo em seus desejos, assim, haveria um descompasso entre sua identidade elaborada socialmente e sua identidade real.

Em um país no qual a identidade externa é notadamente construída em torno do binômio carnaval e futebol, em nosso recorte espacial, a identidade social externa mais natural considerou a presença da Escola de Samba Beija-Flor no município. Desse modo, a Agremiação carnavalesca de Nilópolis se impõe de maneira hegemônica enquanto formadora de identidade local. Independentemente da porcentagem local de residentes que torcem pela Escola, os atores endógenos a associam inequivocamente aos moradores de Nilópolis. Isso expõe como a identidade é trabalhada a partir de uma homogeneidade que exclui eventuais minorias.

É a partir desse mecanismo, comprometido apenas com o significado, que a formação da identidade coletiva mascara a identidade pessoal existente em seu interior. Por esse processo, a maioria acaba sendo tomada como o todo e a identidade se legitima. Esse processo foi classificado por Castells (1999) como identidade legitimadora. Para esse autor, esse tipo de identidade constitui-se aquela em que os dominadores impõem a outro grupo. Há ainda, para o autor, um tipo de identidade de resistência criada pelo grupo que se sente inferiorizado pelo dominante. A terceira 
forma de identidade seria a de projeto, a qual prescinde de uma transformação mais efetiva sobre a conjuntura sociopolítica.

Mesmo correndo o risco de incorrer em distorção ou simplificação da ideia preconizada por Castells, uma vez que nem sempre teoria e prática se encaixam de forma harmoniosa, nos permitirmos o exercício de considerar as formulações do autor para nossa discussão. Castells alerta sobre as eventuais correlações entre as três categorias de identidade por ele aludidas, contudo, não considera a possibilidade de coexistência entre as tipologias identitária que apresenta. Entendemos que a Beija-Flor encerra duas dimensões identitárias concomitantemente. A primeira, considerando sua relação com os residentes de Nilópolis e a segunda, enfatizando a maneira pela qual ela passou a se inserir no mundo do samba.

Conforme mencionado, a identidade em Nilópolis é amplamente ancorada na Agremiação carnavalesca. Essa associação passou a ser superdimensionada a partir da segunda metade da década de 1970 . Todavia, ao mesmo tempo em que consolidava uma identidade legitimadora em seu município sede, a Beija-Flor operava uma identidade de resistência no âmbito das disputas das Escolas de Samba do Rio de Janeiro, a qual, até então, se limitava a uma disputa carioca e não fluminense.

Romper a hegemonia das maiores Agremiações cariocas ou mesmo se inserir no circuito do samba constituía em uma empreitada complexa mesmo para instituições e bairros da cidade do Rio de Janeiro. A Unidos de Vila Isabel, fundada em 1946 no bairro de mesmo nome, se valeu da produção de seu sambista mais ilustre para alcançar esse propósito. Em samba de 1935, intitulado "Palpite infeliz", Noel Rosa desconsiderava qualquer eventual pretensão de superioridade da Vila Isabel sobre os bairros de sambistas já consolidados. Para isso, questionava aqueles que assim pensavam e em seguida, o poeta da Vila enaltece os berços do samba e explicado sua real intenção: Quem é você que não sabe o que diz?/ Meu Deus do Céu, que palpite infeliz!/ Salve Estácio, Salgueiro, Mangueira, Oswaldo Cruz e Matriz/ Que sempre souberam muito bem / Que a Vila Não quer abafar ninguém/Só quer mostrar que faz. samba também".

Dessa maneira, em 1946 a Vila de Noel alertava através desse samba que aqueles que não compreendiam suas intenções, como o sambista Wilson Batista, incorriam em um "palpite infeliz". Em 1976, a Beija-Flor de Neguinho asseverava na letra do samba-enredo daquele ano, o qual homenageava o jogo do bicho, que "nesta festa de real valor, não erre não/ O palpite certo é Beija-Flor”. Assim, seja pelo palpite infeliz ou pelo certo, da mesma forma que a azul e branco de Noel, a azul e branco de Neguinho não queria "abafar ninguém, só queria mostrar que Nilópolis fazia samba também".

É nesse sentido, ao intentar superar a condição de "escola roceira" para se inserir no rol das grandes Agremiações do carnaval fluminense, que a Beija-Flor, enquanto instituição promoveu uma identidade de resistência, pois para Castells $(1999$, p. 24) esse tipo de identidade é "criada por atores que se encontram em posições/condições desvalorizadas e/ou estigmatizadas pela lógica da dominação".

Neste contexto específico, circunscrito a segunda metade da década de 1970, a Beija-Flor conjugava uma identidade legitimadora, na escala municipal entre seus residentes, e uma identidade de resistência, considerando o universo das disputas carnavalescas. Entretanto, no período atual a identidade de resistência foi superada. É pouco provável que algum analista de carnaval caracterize a Escola de Nilópolis como pequena ou "roceira". O caso em questão atesta a transformações pela qual a identidade pode passar, conforme pontuou Castells (1999, p. 24) quando lembra que "identidades que começam como resistência podem acabar resultando em projetos, ou mesmo 
tornaram-se dominantes nas instituições da sociedade, transformando-se assim em identidades legitimadoras para racionalizar sua dominação".

Por essa perspectiva, o caso da Beija-Flor, que almejava o mesmo patamar das suas concorrentes cariocas, compromete ainda a noção segundo a qual a identidade sempre parte do pressuposto de diferenciação. Contudo, a luta encapada pela Escola seria por igualdade com as irmãs cariocas e não pela diferenciação. Tal fato expõe, mais uma vez, a multiplicidade envolvida na dimensão da identidade, pois ela pode gerar conflitos na busca por ser igual como também alimentar a busca em ser diferente.

A identidade, seja a individual ou a coletiva, necessita de elementos para sua produção. $\mathrm{Na}$ ausência de símbolos capazes de reunir "corações e mentes" em prol da construção de uma identidade, os líderes desse processo podem lançar mão da "invenção da tradição". No caso da identidade ancorada na Beija-Flor, não houve a invenção de uma tradição nos termos consagrados pelo autor, mas sim a produção de uma identidade. A invenção exige criar elementos identitários a partir de eventos inexistentes, já a produção da tradição consiste em maximizar a potencialidade identitária através de um elemento real. Nesse sentido, baseado em Hall (2006), Simões (2008, p. 37) "chama atenção para a estratégia do resgate positivo de um determinado acontecimento histórico que passa a ser considerado como chave para o surgimento de uma comunidade". Os dirigentes da Escola de Samba utilizaram o tricampeonato nos anos de 1976, 1977 e 1978 como acontecimento histórico inicial para a construção da identidade nilopolitana. Para Sant'anna Junior (2010, p. 42),

\begin{abstract}
com essas vitórias, a população de Nilópolis se mostrava orgulhosa pelas conquistas alcançadas, iniciando dessa forma o sucesso que viria contribuir para que a identidade do Município fosse aos poucos construída. A Baixada Fluminense que sempre viveu as margens da cultura, agora era destaque, $o$ centro das atenções. As conquistas da Beija Flor serviram para ressaltar a existência do Município de Nilópolis, para determinar o início de uma era de profissionalismo das escolas de samba, e para reforçar toda uma política patriarcal no Município.
\end{abstract}

A partir do exposto, o quadro 1 sintetiza as tipologias de identidade que a BeijaFlor construiu no município considerando a terminologia empregada pelos autores trabalhados. Essa síntese é importante, pois almejamos delimitar as dimensões variáveis pela qual a identidade opera. Desse modo, essa reflexão aponta que a azul e branco de Nilópolis impõe identidades classificadas em quatro tipos: simbólica, parcial, coletiva e legitimadora.

Quadro 1- Tipologias de identidades as quais a Beija-Flor de Nilópolis encerra sobre o município

\begin{tabular}{|c|c|}
\hline Tipos & Caracterização \\
\hline Simbólica & $\begin{array}{l}\text { Assentada, mormente, pelas características culturais que a } \\
\text { Agremiação emana. }\end{array}$ \\
\hline Parcial & Alicerçada a partir da escala municipal. \\
\hline Coletiva & $\begin{array}{l}\text { Amplamente identificadora do município para os agentes externos, } \\
\text { excluindo-se eventuais distinções internas. }\end{array}$ \\
\hline Legitimadora & Instituição identitária hegemônica em Nilópolis. \\
\hline
\end{tabular}

Fonte: Elaborado por Albuquerque, 2018, a partir de CASTELLS (1999), HALL (2000) e MEDEIRO (2002). 
Nesse sentido, a noção simbólica da Agremiação expõe a natureza dessa identidade; a parcial demarca a escala geográfica de seu alcance; a coletiva afirma a força dessa identidade para além do limite da atuação física da Escola e a legitimadora revela o poder oriundo da soma das três tipologias anteriores.

Essa característica de legitimadora da identidade nilopolitana exclusivista da Beija-Flor, a qual sintetiza as demais tipologias apresentadas no quadro acima em si, torna a identidade erigida por essa instituição merecedora de um enfoque social. Como a identidade é uma construção social amplamente assentada sob o espaço vivido, a BeijaFlor consolida a identidade entre seus simpatizantes pela perspectiva cultural.

Já entre aqueles que não se identificam com a Escola, essa identificação se impõe na medida em que ela representa o município de Nilópolis, o qual, por sua vez, constitui o espaço vivido de seus moradores. Por meio dessa lógica assentada nas significações, ser de Nilópolis é, por extensão, ser Beija-Flor. É dessa forma que Claval (1999, p. 10) entende que

\begin{abstract}
os traços que caracterizam as pessoas são tão numerosos que somente uma parte é retida para definir a identidade. Isto significa que, a partir da mesma situação, outras conceitualizações seriam possíveis. Mas a identidade, uma vez definida, contribui para fixar a constelação de traços que ela reteve, e subtraí-los dos desgastes do tempo.
\end{abstract}

A seletividade aludida por Claval no contexto nilopolitano é amplamente reforçada nos meios midiáticos. O site $\mathrm{G} 1$, especializado em informação e vinculado a maior organização televisiva do país, releva essa associação entre Nilópolis e a Agremiação. O site possui uma ferramenta de busca na qual o usuário pode efetuar pesquisas sobre reportagens referentes ao município selecionado. Em pesquisa realizada em 02/02/2018 sobre o município nilopolitano, entre as 13 últimas notícias postadas, 8 delas tinham relação com a Beija- Flor. Logicamente que o mês no qual a pesquisa é realizada influi nos resultados obtidos, uma vez que próximo ao período carnavalesco a tendência é que mais informações relacionadas à Agremiação sejam produzidas. Contudo, esse resultado compreende a pesquisa referente às notícias postadas no intervalo de um ano.

Apesar dessa constatação cristalina, Claval (1999, p. 24) alerta que um olhar culturalista pode impor o risco de "fabricações de discursos identitários ao invés de lhes considerar a partir de um olhar crítico", cabendo ao pesquisador o papel não de "forjar ideologias, mas o de desmontar seus mecanismos e o de fazer compreender para que elas servem e que perigos elas implicam". Dessa maneira, precisamos atentar sobre o perigo escamoteado na produção do discurso considerando que toda identidade esconde um projeto político.

Como reflexo de ter sido produzida, a identidade tem um compromisso político, pois toda construção social expressa, concomitantemente, relações de poder. O poder, por sua vez, está na essência da constituição dos territórios. Em razão disso, de acordo com Medeiros (2009, p. 217-218),

não se pode julgar perigoso o território porque ele traz em si esta noção de poder e de afirmação identitária. Esta é uma realidade que está inscrita no espaço e no tempo e que lhe dá a garantia de existência [...] O território é pois, esta parcela do espaço enraizada numa mesma identidade e que reúne indivíduos com o mesmo sentimento.

Dessa maneira, objetivamos que a discussão salientada até aqui tenha respondido como, por quem e a partir de que essa identidade foi construída em 
Nilópolis. Nossos objetivos a partir de então, intenta responder para que essa identidade construída se presta. Nesse sentido, a parte seguinte deste artigo ambiciona esmiuçar a natureza do território nilopolitano considerando sua contextualização histórica e geográfica no âmago da Baixada Fluminense.

\section{IDENTIDADE CONSTRUÍDA, USO POLÍTICO DETERMINADO: CARNAVAL E POLÍTICA NO CONTEXTO NILOPOLITANO}

O atual presidente de honra da Beija-Flor, Anísio Abraão David, " foi camelô nos trens da Central e cobrador de aluguéis em Nilópolis, até descobrir, ainda jovem, o bicho que não tinha um líder claro na cidade. Com Nelson, um dos irmãos mais novos, como braço direito, assumiu o posto ainda nos anos 1960" (MOTTA, 2012, p. 107). A entrada da família Abraão na contravenção explicaria o domínio sobre a Agremiação anos mais tarde. Isso porque a associação entre as Escolas de Samba e o jogo do bicho estava relacionada à maneira pela qual ocorria o financiamento dessas agremiações em um primeiro momento.

O carnaval não tinha o prestígio social e cultural observado atualmente. Inicialmente estava associado à "malandragem", de modo que as pessoas mais conservadoras não investiam nos chamados livros de ouro, o qual consistia no "registro da captação de recursos financeiros que permitiriam a realização dos eventos carnavalescos" (REIS, 2012, p. 9). Bezerra (2010, p. 90) exemplifica esse estigma por meio do depoimento de uma ex-componente da Beija-Flor, a qual recorda que, "a gente às vezes passava pelo comércio com o 'livro de ouro' e ouvia um monte de coisas: 'eu vou dar dinheiro pra Escola de Samba? Aquele lugar é cheio de vagabunda!'. E a gente saía morrendo de vergonha".

Ao contrário de alguns comerciantes, os quais precisavam garantir uma clientela fiel e para isso se preocupavam em ter conduta "ilibada", sobre os "corretores zoológicos" não havia o peso moral em razão da natureza de suas operações de já ser consideradas ilegais. Além disso, os apostadores compreendiam, em grande medida, os adeptos do mundo do samba. Por essa razão, "desde as primeiras décadas de desfile, bicheiros assinavam os livros de ouro que os sambistas passavam entre os comerciantes do bairro para recolher dinheiro e comprar material para fantasias" (JUPIARA e OTAVIO, 2016, p. 84). Com efeito, entre os "populares", os banqueiros do jogo do bicho eram os que possuíam mais recursos financeiros, logo eram os que realizam as maiores contribuições.

Por meio dessa configuração financeira, o grupo de contraventores foi paulatinamente ganhando espaço dentro das agremiações até assumirem a presidência das mesmas de forma direta ou indireta. Em contraste com a ascensão da família libanesa no ramo da contravenção nos anos 1960, a Beija-Flor amargava nesse período posições modestas no segundo e terceiro grupos do carnaval. Em decorrência dessa disparidade, de um lado existia a fome pelo poder e do outro a vontade de vencer. Foi um casamento perfeito. A Escola entraria com a legitimação social e cultural, os Abraão com a força financeira para construir a ascensão da instituição. Com efeito, "em 1967, Anísio e Nelson deram todo o apoio possível ao presidente da escola, Heitor Silva, fazendo com que a Agremiação voltasse a desfilar em 1968 no Grupo II. Nesse ano, Anísio assume a presidência da escola [...]" (REVISTA BEIJA-FLOR, 2013, p. 8).

Bezerra (2010) sugere que a rápida passagem de Anísio como presidente da Beija-Flor em 1968, se deveu ao fato de ele ainda não estar devidamente estruturado com o jogo do bicho. Entretanto, para esse mesmo autor (p. 143), Anísio não era um contraventor que "de uma hora para outra, resolveu ampliar sua influência social 
apoiando a Agremiação carnavalesca". Reforçando este argumento, Motta (2012, p. 103) conta que a chegada do mecenas à Agremiação ocorreu em consequência de uma paixão de seu irmão, Nelson, por uma "linda mulata 'do' Beija-Flor chamada Marlene". Antes, os irmãos frequentavam o tradicional bloco carnavalesco "Centenário", rival local da azul e branco. A paixão de Nelson Abraão o fez deixar o bloco e convencer o irmão mais velho a também ingressar na Beija-Flor. Após o casamento na década de 1970 de Nelson Abraão e Marlene Sennas, filha do ex-presidente da Beija-Flor, José Sennas e com o apoio conquistado no final da década anterior junto ao então presidente Heitor Silva, a família Abraão conquistou a presidência da Beija-Flor em 1972. Sobre esse processo, Cavalcanti (2009, p. 98) explica que

\begin{abstract}
demarcaram-se grandes áreas territoriais de atuação de banqueiros e o controle de um determinado território implicou, via de regra, a aproximação do banqueiro com as agremiações populares nele sediadas (futebol e carnaval). Esse movimento significou a um só tempo aquisição de prestígio e visibilidade e a consolidação de formas de mando e de controle capilares por parte dos bicheiros. Nos anos 1970, em especial, um novo tipo de presença do banqueiro no universo das escolas de samba se fez notar com nitidez. Esse processo ainda demanda pesquisas, mas sabe-se que data daí, por exemplo, a desde então bem estabelecida presença de Anísio Abraão Davi na Beija-Flor, que correspondeu ao crescimento da presença política de seus familiares na região de Nilópolis.
\end{abstract}

Nessa conjuntura, com o aporte financeiro oriundo da contravenção e sob a benção política das famílias Sennas e da Silva, celebrou-se o casamento entre a família Abraão e a família Beija-Flor. Aliado a essa articulação político-familiar, "os anos de chumbo promoveram [...] a ascensão de barões do bicho, que, alçados a condição de patronos de escolas situadas em seus territórios de jogo, as arrebataram para si, usandoas para proteger seus negócios e garantir sua escalada social", conforme concluem Jupiara e Otavio (2016, p. 85) em seu livro no qual trata da ascensão do jogo do bicho no período militar.

A publicação oficial da azul e branco de Nilópolis registra, por outro viés, aquilo que Jupiara e Otavio (2016) classificaram como uma estratégia de ascensão social. De acordo com a publicação (REVISTA BEIJA-FLOR, 2007, p. 75-76), após estar com "sua vida financeira estabilizada", o que pode ser entendido como a consolidação dos pontos de jogo do bicho em territórios bem delimitados, Anísio Abraão

\footnotetext{
parte para novos desafios, investindo parte dos seus recursos em atividades sociais e na reconstrução da Escola de Samba Beija-Flor de Nilópolis, para fazer dela o que é hoje: a melhor Escola de Samba do mundo [...]. Anizio injetou recursos, que melhoraram as instalações, contrataram profissionais de qualidade e deram um novo ânimo à escola, até que no ano de 1976 uma desconhecida Escola de Samba de um desconhecido município da Baixada Fluminense invade a cidade do Rio de Janeiro e conquista o título de campeã do Grupo I do Carnaval Carioca, à época o principal Desfile das escolas de samba do Rio de Janeiro. Consolidava-se, assim, uma nova fase na vida da Beija-Flor de Nilópolis, do povo nilopolitano e de todo o povo da Baixada, que encontrou na escola um motivo de orgulho e motivação.
}

Inegavelmente a família libanesa elevou o patamar competitivo da azul e branco de Nilópolis. Os gráficos abaixo apontam para essa reflexão. Se dividirmos as posições conquistadas pelo número de disputas, no período anterior à gestão da família Abraão a Escola teve uma de 6,89. Ou seja, no período compreendido entre 1954 e 1972, a azul e branco de Nilópolis tendia a ocupar as posições entre $6^{\mathrm{a}}$ e $7^{\mathrm{a}}$ colocadas (Gráfico 1). 
Gráfico 1 - Colocações da Beija-Flor no período anterior e durante a gestão dos Abraão

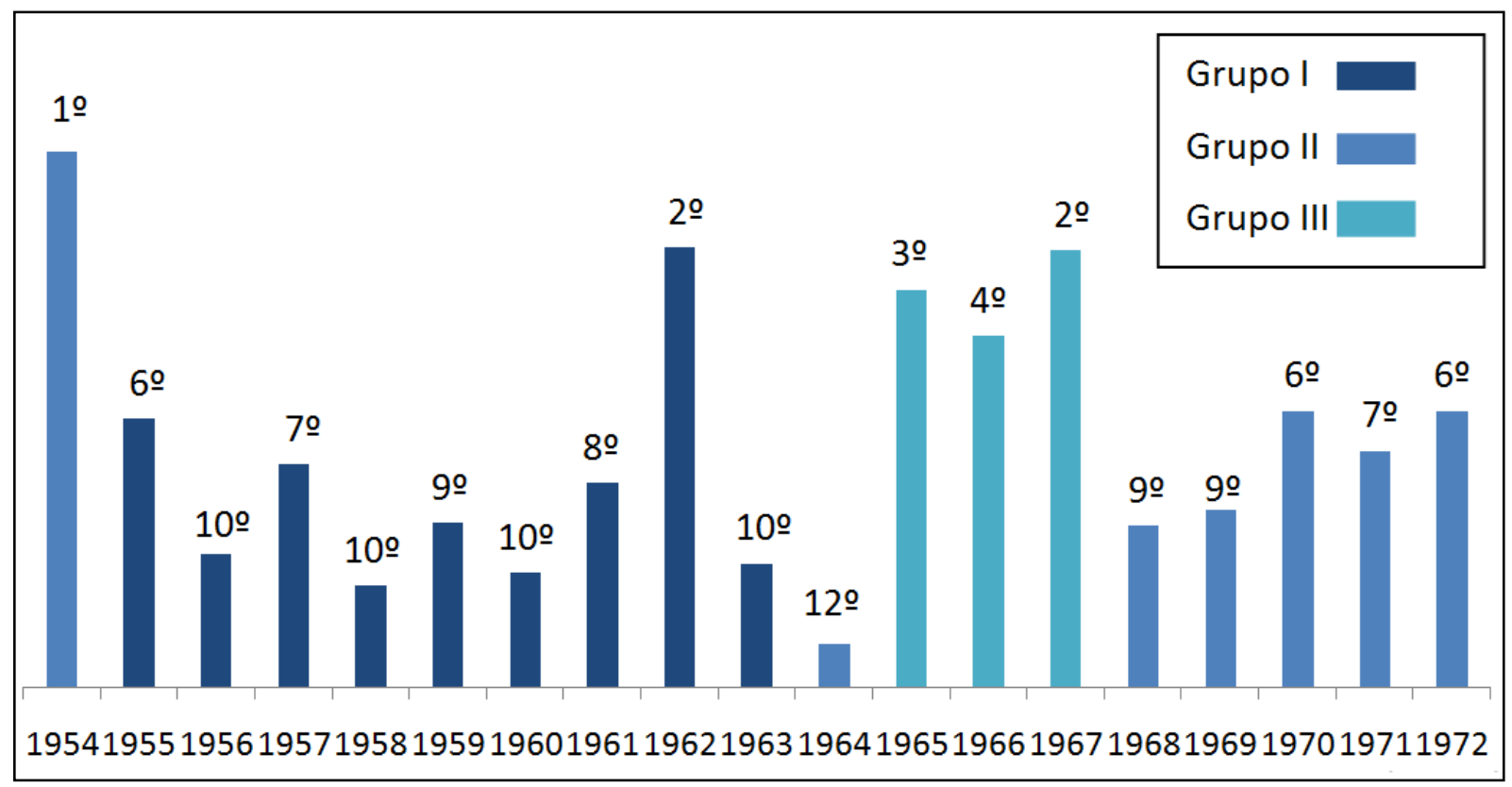

Fonte: Elaborado pelo autor a partir de REVISTA BEIJA-FLOR (2002)

No período relativo à gestão dos libaneses, esse índice fica em 2,76. Desse modo, entre 1973 e 2018 a média da Agremiação oscilou entre a $2^{a}$ e $3^{a}$ posições. Cabe ainda salientar que durante a gestão dos Abraão, a qual até 2018 somava 46 disputas, apenas em um ano a Beija-Flor não estava no grupo principal, justamente em 1973 quando conquistou o direito de participar do primeiro grupo. Além de expressar a longevidade da família no comando da Escola, o gráfico também acentua a eficiência de sua gestão.

Gráfico 2 - Colocações da Beija-Flor durante a gestão dos Abraão

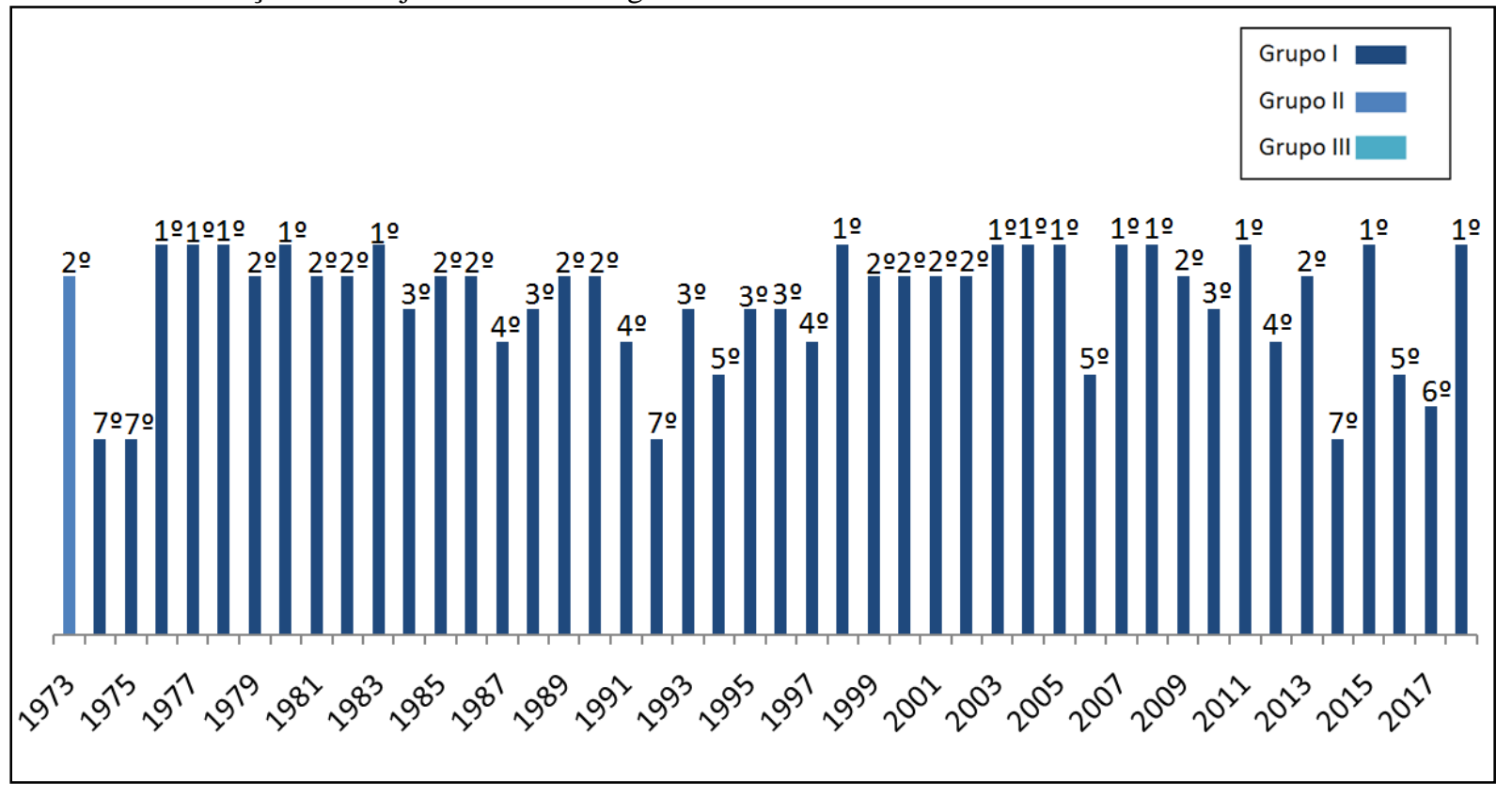

Fonte: Elaborado pelo autor a partir de REVISTA BEIJA-FLOR (2002) e do site www.academiadosamba.com.br/memoriasamba 
Aliado à eficiente gestão da Escola de Samba, a família Abraão passou a usar o prestígio da instituição para uso político eleitoral próprio, vinculando o nome de seus membros aos projetos sociais realizados pela família via Beija-Flor, dentre os quais se destacam uma creche, um educandário e um centro de atendimento aos moradores locais.

Segundo a Revista da Beija-Flor (2004), a Creche Júlia Abraão David, nome que presta homenagem a mãe de seu mantenedor, Aniz Abraão, foi inaugurada em 9 de maio de 1980 e atende a crianças de seis meses a seis anos de idade em regime de semiinternato prestando, também, atendimento médico e odontológico para seus alunos. Para conseguirem vaga, os pais devem ter renda familiar inferior a três salários mínimos e não podem estar desempregados. Caso o responsável esteja sem emprego, a direção da creche estipula um prazo que varia de 30 a 60 dias para que consiga ocupação, ajudando-o nessa procura por meio de convênios firmados com o comércio local. As crianças assistidas pela creche já têm vaga assegurada no Educandário Abraão David, quando completam seis anos de idade, deixando-o apenas quando concluem o nono ano do Ensino Fundamental. O Educandário atende atualmente cerca de mil alunos.

O Centro de Atendimento Comunitário Nelson Abraão David (CAC/NAD) fundado em 1981, fecha o ciclo educacional idealizado pela família Abraão, pois objetiva qualificar profissionalmente adolescentes e adultos carentes de Nilópolis e dos municípios próximos por meio de parcerias com instituições como o Serviço Nacional de Aprendizagem Industrial (SENAI), Serviço Nacional de Aprendizagem Comercial (SENAC), Centrais Sindicais, Universidades e empresas privadas. Os cursos oferecidos se dividem em comercial e industrial. Nos cursos comerciais há oportunidade para as áreas de informática, telemarketing, técnico de vendas, atendimento, turismo, garçom, inglês, espanhol, cabeleireiro, manicure, corte e costura e culinária. No setor industrial há cursos para eletricista, marcenaria, gráfica, refrigeração, hidráulica e mecânico de motor. Há ainda cursos de dança de salão, aerodança, dança do ventre, karatê, capoeira e ginástica. O CAC/NAD ainda presta assistência social à população na área de clínica médica, nas especialidades de psicologia, jurídica, pediátrica, angiológica, nutrição e odontológica (REVISTA BEIJA- FLOR, 2004). Em razão da associação direta da família com a Beija-Flor, as obras sociais da Agremiação são creditadas aos membros com atuação política, conforme registra a figura 3 .

Além das atividades sociais mais abrangentes, outras de cunho mais imediatistas contribuíram para a popularização desse clã como a doação de brinquedos, roupas e doces feita anualmente na quadra da Escola de Samba no dia das crianças, e também, a doação de 6.000 cestas básicas mensais aos moradores locais, segundo o site da escola. A Agremiação desfila no carnaval com cerca de três mil os componentes da própria comunidade, os quais recebem a fantasia gratuitamente. Considerando que a Escola desfila com quatro mil componentes em média, o somatório dos integrantes entre aqueles que desfilam pela sem custos de adereços corresponde a 75\% do total. Enquanto as demais Escolas de Samba tinham como rainhas de bateria personalidades midiáticas sem vínculo com a localidade, na Beija-Flor essa escolha era feita entre as passistas moradoras do município. Assim foi com Sônia "Capeta" ocupante do cargo até o ano de 2002, quando passou a função para a jovem Raíssa, também moradora de Nilópolis. 
Figura 3 - Publicidade política relacionando o clã libanês à Agremiação e suas obras sociais.

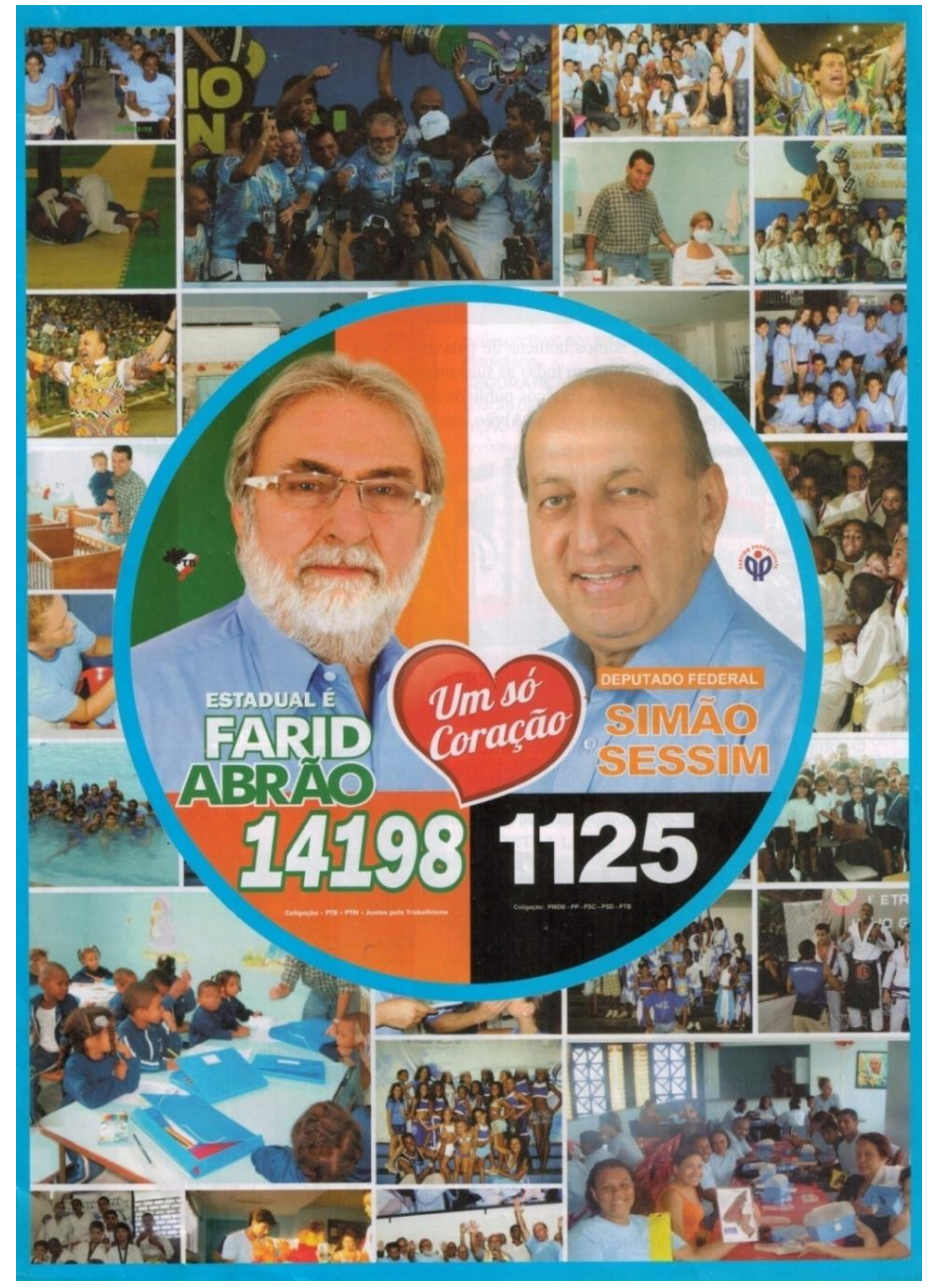

Fonte: Acervo de Enderson Albuquerque, 2014.

A direção da Escola, ao acrescentar ao final do nome da Agremiação o nome da cidade, consolidou, de maneira mais nítida, a associação já existente entre o município e a Agremiação. A cidade passou a ser conhecida, tanto no cenário nacional quanto no internacional, por meio da Beija-Flor. Ao "vender" a cidade via Beija-Flor, a Agremiação, sobretudo nos meios midiáticos, acaba sobrepondo-se a toda uma cidade. A associação entre a cidade de Nilópolis e a Escola de Samba acaba por fazer crer que a existência da primeira depende da presença da segunda. Dessa forma, Nilópolis não é mais uma cidade sediando uma Escola de Samba e sim a Beija-Flor que passa a ser uma Escola de Samba dominando uma cidade através da atuação política de seus gestores.

Como exposto linhas acima, a primeira vez que um membro do clã assumiu a presidência da Beija-Flor foi de forma interina em 1966 com Aniz Abraão. A partir desse ano até o momento atual, a Agremiação só não foi presidida por um Abraão David em dois momentos: entre 1966 e 1972 com Heitor Silva (aliado do clã) e entre 1992 e 1993 quando assumiu o vice-presidente, Luiz Carlos Duarte Baptista, por causa do suicídio do presidente à época, Nelson Abraão. Além dos Abraão já citados, presidiram a escola ainda Farid Abraão (1984-1992, 1994-2001 e 2013-2016), Nelsinho Abraão (2012-2013) e Ricardo Abraão (2016 a presente data).

A cronologia das gestões municipal e da Agremiação indica o domínio da família nesses espaços. Em 1973, Nelson Abraão foi o primeiro membro da família a assumir a Escola de Samba sem ser interino. Depois dele não houve nenhum outro 
presidente eleito sem Abraão como sobrenome. Em 1973, Simão Sessim, primo dos Abraão, tornou-se o primeiro do grupo libanês a assumir a prefeitura de Nilópolis. Depois dele apenas um prefeito eleito não pertencia ao grupo ou não havia sido lançado politicamente por eles, conforme indica o quadro 2.

Quadro 2- Prefeitos de Nilópolis - 1973-2015.

\begin{tabular}{|l|l|}
\hline Nome & Período \\
\hline Simão Sessim* & 1973 a 1977 \\
João Batista da Silva*** & 1977 a 1981 \\
Zélio Sabino Barbosa *** & 1981 a 1982 \\
Miguel Abraão* & 1983 a 1988 \\
Jorge David * & 1988 a 1992 \\
Manoel da Silva Rosa ** & 1992 a 1996 \\
José Carlos Cunha** & 1996 a 2000 \\
Farid Abraão * & 2001 a 2008 \\
Sérgio Sessim* & 2009 a 2012 \\
Osvaldo Costa ** & 2012 \\
Alessandro Calazans & 2013 a 2016 \\
\hline$*$ Familiares do clã Abraão-Sessim & \\
$* *$ Membros indiretos do clã Abraão-Sessim & \\
$* * *$ Interventores federais & \\
\hline
\end{tabular}

Fonte: Organizado pelo autor a partir do site www.nilopolis.rj.gov.br.

Todo esse apelo simbólico emanado pela instituição ao ser apropriado pelo grupo libanês permitiu proezas políticas também nos legislativos municipal, estadual e federal. Desde o ano de 1972 o clã mantém ao menos um representante direto na Câmara Municipal de Nilópolis. Na esfera estadual os sírio-libaneses em questão só não tiveram representantes na legislatura de 2007-2010. Desde 1978 Simão Sessim representa o grupo na Câmara Federal sendo o deputado mais antigo da casa com dez mandatos consecutivos.

Embora seja verdade que um membro do referido grupo já era prefeito de Nilópolis em 1973, ou seja, antes de a Agremiação ganhar destaque no cenário carnavalesco, a projeção alcançada pela Beija-Flor com o tricampeonato permitiu a esse grupo um espaço de exposição de seus feitos gerenciais não possível a nenhum outro adversário político da cidade. Ao assumir a presidência da Escola e, consequentemente, se colocar como representante da mesma, os Abraão "obrigavam partidos e máquinas políticas interessados em explorar o reduto eleitoral da escola a se relacionarem com eles" (BEZERRA, 2013, p 7). Dessa maneira, o domínio da Escola de Samba ampliou, consideravelmente, as possibilidades políticas do clã Abraão-Sessim.

Por meio de uma retroalimentação, os libaneses se beneficiam da "marca" BeijaFlor para arrecadar votos e com o auxílio dos mandatos conseguidos passam a beneficiar a Agremiação e suas obras sociais com recursos públicos. O grupo já utilizou sua posição política para favorecer a Agremiação carnavalesca. Como apontou Motta (2012, p. 111), em 1974, Simão Sessim "usou sua caneta de prefeito para asfaltar a Rua José Bittencourt, só para que os carros alegóricos, feitos no barracão do bairro Nova Cidade, pudessem chegar a salvo até a Via Dutra e de lá seguir viagem para o Rio".

Ademais, convém salientar seu uso para o domínio político-eleitoral de um grupo que se apossou de uma instituição para uso privado, pois além de conseguir os votos dos nilopolitanos nas eleições, os membros dirigentes se utilizam da Agremiação de forma ideológica, apresentando enredos que lhe sejam convenientes politicamente, 
como forma de agradar ao grupo político dominante, não importando o espectro político ao qual esse grupo pertença. Nesse sentido, Motta (2012, p. 90) sustenta que

da ditadura aos governos mais progressistas, a azul e branco celebrou presidentes e cenários institucionais do país em enredos os mais variados. Numa mistura de fascínio e fisiologismo, construiu, em alguns de seus temas, versões camaradas de regimes e governantes muito questionados. Na hora de unir política e samba, a Beija-flor veste a fantasia de Camaleão.

\section{CONSIDERAÇÕES FINAIS}

A partir do exposto, nossa reflexão apontou que a azul e branco de Nilópolis impõe identidades classificadas em quatro tipos: simbólica, parcial, coletiva e legitimadora. Nesse sentido, a noção simbólica alude à natureza cultural pela qual essa identidade é constituída, pois se assenta sobre a Agremiação carnavalesca. O território, na acepção de Haesbaert (2014), compreende as perspectivas política, econômica e cultural. Tais fatores podem atuar conjuntamente para construir um território. Contudo, embora as três esferas aludidas por Haesbaert sejam capazes de criar identidades, isso porque ela é sempre uma construção sociocultural, a esfera cultural é aquela capaz de forjar as identidades de modo mais efetivo e complexo em nosso recorte. Com efeito, a primeira tipologia identitária em Nilópolis emana do aspecto simbólico.

Embora sua ascensão carnavalesca em alguma medida tenha permitido a ressignificação da Baixada Fluminense na década de 1970, a Agremiação concorre com outras instituições e agentes na formação identitária entre os residentes dos municípios baixadianos. Assim sendo, apesar do vigor da identidade beijafloriana, ela opera com maior força em um limite espacial determinado: a escala municipal nilopolitana, na qual ela não encontra nenhum concorrente. Por esse motivo, essa tipologia se enquadra, também, como uma identidade parcial.

Como reflexo de ser mais efetiva na escala local, essa identidade entendida como parcial quando se considera a Baixada Fluminense como um todo, acaba por se traduzir em uma identidade coletiva quando se considera o município de Nilópolis especificamente. Em razão de sua força, a identidade ancorada sobre a Beija-Flor é amplamente difundida como a mais legítima do espaço nilopolitano. Esse processo elimina eventuais distorções internas transformando, assim, a Agremiação azul e branca em portadora hegemônica da identidade nilopolitana. Por essa razão, a identidade beijafloriana assume uma dimensão legitimadora.

Assim, embora o título desse artigo questione se Nilópolis seria da Beija-Flor, é importante salientar que essa instituição forja uma identidade na qual os benefícios políticos do processo são extraídos por seus membros dirigentes. Em nossa concepção, a instituição carnavalesca não cria o território propriamente dito. No limite, a Beija-Flor promove a identidade, o território, por sua vez, é construído pela família Abraão.

O tricampeonato da Beija-Flor na segunda metade da década de 1970 contribuiu decisivamente para a mitificação da família Abraão e sua imediata associação à Agremiação e foi ampliado mediante os projetos sociais mantido pelos libaneses via Agremiação. À proporção que a Escola foi ganhando destaque no cenário estadual e nacional, o grupo libanês foi, concomitantemente, se beneficiando dessa expressão conquistada passando a converter, de forma mais direta, esses ganhos em projeção política.

Considerando essa discussão, Castells (1999, p. 23), expõe não ser "difícil concordar com o fato de que, do ponto de vista sociológico, toda e qualquer identidade é construída. A principal questão, na verdade, diz respeito a como, a partir de quê, por 
quem, e para que isso acontece". Dessa maneira, objetivamos que a discussão empreendida por este artigo tenha respondido como, por quem e a partir de que essa identidade foi construída em Nilópolis. Quanto à última questão formulada por Castells, para que essa identidade construída se presta, no caso em questão defendemos que ela serviu para ampliar o poder político da família Abraão no município de Nilópolis.

\section{NOTAS}

1- Existem controvérsias quando a formação dessa tríade, pois a Portela, surgida a partir do Bloco Conjunto Oswaldo Cruz em 1923, se considera a Escola de Samba mais antiga em atividade permanente. Contudo, a alteração para o nome Portela ocorreu somente em 1935.

\section{REFERENCIAS}

BEZERRA, Luiz Anselmo. A família Beija-Flor. 2010, 243 p. Dissertação (Mestrado) -Universidade Federal Fluminense, Instituto de Ciências Humanas e Filosofia, Departamento de História, 2010.

A Interferência Militar na Baixada Fluminense e o Domínio Familiar em Nilópolis. REVISTA GEONORTE. Edição Especial 3, V.7, N.1, p.831-848, 2013.Disponível em www.encontro2010.rj.anpuh.org.

BONNEMAISON, Joel. Viagem em Torno do Território. In: CORRÊA, Roberto Lobato \& ROSENDAHL, Zeni. (Org.). Geografia Cultural. Rio de Janeiro: Editora UERJ, 2002.

CARDOSO, Ernesto. Nilópolis de Hontem e de Hoje. Nilópolis: L \& J. Berkowitz, 1938.

CASTELLS, Manuel. O Poder da Identidade. São Paulo: Paz e Terra, 1999.

CAVALCANTI, Maria Laura Viveiros de Castro. Festa e contravenção: os bicheiros no carnaval do Rio de Janeiro. In: CAVALCANTI, Maria Laura Viveiros de Castro; GONÇALVES, Renata (orgs.). Carnaval em múltiplos planos. Rio de Janeiro: Faperj, 2009. p. 91-123.

ClAVAl, Paul. O Território na Transição da Pós-Modernidade. Revista GEOgraphia da UFF, Niterói- RJ, ano 1, N 2, p. 07-26, maio-1999.

GRACHER, Kherian Galvão Cesar. É a identidade fundamental? 2016, 111 p. Dissertação (Mestrado). Universidade Federal de Santa Catarina (UFSC), Florianópolis, 2016.

HAESBAERT, Rogério. O mito da desterritorialização: do "fim dos territórios" à multiterritorialidade. Rio de Janeiro: Bertrand Brasil, 2014.

HALL, Stuart. Quem precisa de identidade? In SILVA, Tomaz de. Identidade + diferença. Petrópolis: Vozes, 2000. 
Identidade cultural na Pós-modernidade. Rio de Janeiro: DP\&A, 2006.

JUPIARA, Aloy; OTAVIO, Chico. Os Porões da Contravenção: jogo do bicho e ditadura militar: a história da aliança que profissionalizou o crime organizado. Rio de Janeiro: Record, 2016.

MARAFON, Gláucio José; RIBEIRO, Miguel Angelo; CORRÊA, Renata da Silva; VASCONCELOS, Vinícius Neves. Geografia do Estado do Rio de Janeiro: da compreensão do passado aos desafios do presente. Rio de Janeiro: Gramma, 2011.

MEDEIRO, Marília Salles Falci. A construção teórica dos conceitos de socialização e identidade. In: Revista de Ciências Sociais, 2002, v. 33 n 1, pp. 78-86.

MEDEIROS, Rosa Maria Vieira. Território, espaço de identidade. In: SAQUET, Marcos Aurelio; SPOSITO, Eliseu Savério (orgs). Territórios e territorialidades: teorias, processos e conflitos. São Paulo: Expressão Popular, 2009. p.217-227.

MOTTA, Aydano André. Maravilhosa e Soberana: História da Beija-flor. Rio de Janeiro: Verso Brasil, 2012.

REIS, Carlos Frederico da Silva. Os Tenentes do Diabo: carnaval, lazer e identidades entre os setores médios urbanos do Rio de Janeiro (1889-1932). 2012, 135 p. Dissertação (mestrado em História) - Pontifícia Universidade Católica do Rio de Janeiro (PUC-RJ), Departamento de História, 2012.

Revista Beija-Flor de Nilópolis: uma escola de vida. Rio de Janeiro: Designum Comunicações, 2002, 2004, 2007, 2013 e 2016.

SANT'ANNA JUNIOR, Daniel de. O Samba como elemento formador da identidade do Município de Nilópolis, relações e interações dos moradores com a Escola de Samba Beija Flor. 2010, 57p. Monografia (Graduação). FEB- Universidade do Estado do Rio de Janeiro, Duque de Caxias, 2010.

SIMÕES, Manoel Ricardo. A Cidade Estilhaçada: Reestruturação Econômica e Emancipações Municipais na Baixada Fluminense. 1 ed. Mesquita-RJ: Entorno, 2008.

TCE. TRIBUNAL DE CONTAS DO ESTADO DO RIO DE JANEIRO. Estudos Socioeconômicos dos Municípios - Edição 2014. Disponíveis em http://www.tce.rj.gov.br. Acessado em 21/10/2015. 